\title{
Mitsunobu Reaction on Solid Support for Peptide $N$-Terminal Farnesylation
}

\author{
Julien Poupart and William D. Lubell \\ Department of chemistry, Université de Montréal, Montreal, Canada
}

\section{Introduction}

Prenylation is an important post-translational modification of peptide structures. For example, farnesylated and geranylgeranylated peptides and proteins bind to cell membranes by way of the prenyl

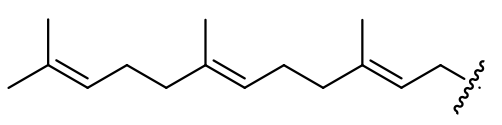
subunit. Prenylation is involved in a wide variety of biological process and diseases, including cancer [1,2] and Alzeimer's disease [2]. Prenylated peptides have been shown to be generally non-toxic and to exhibit cell permeable

Fig. 1. Farnesyl group. properties [3]. Prenylated protein libraries have been used to study various biochemical mechanisms that involve posttranslational prenylation [4]. Prenylated peptides have also been used as prenyltransferase inhibitors [5]. Prenylated peptides may exhibit ability to localize in membranes, which may enhance their metabolic stability and biological presentation.

The conventional way to introduce a prenyl group onto a peptide chain involves nucleophilic displacement by a cysteine residue thiol side chain on a proper prenyl bromide [3]. Prenyl bromides are relatively expensive and unstable. Prenylation on nitrogen has been less well studied, but may offer an alternative way for introducing the lipid moiety onto peptides. In an effort to explore $N$-terminal prenylation, we have explored the Mitsunobu reaction in order to employ the relatively more stable alcohols instead of their prenyl halide counterparts.

For this study, the L-enantiomer (L-PDC-31, Ile-Leu-Gly-His-Cit-Asp-Tyr-Lys) of the D-peptide PDC-31 was chosen [6], in part because this prostaglandin $F_{2} \alpha$ receptor modulator has completed successfully phase $1 \mathrm{~b}$ clinical trials in which toxicity was assessed in women suffering from primary desmenorea [7]. Hypothesizing that the L-isomer may be active, yet rapidly degraded in biological tissues, a farnesyl chain at the $N$-terminal nitrogen has been examined to increase metabolic stability of the peptide. Herein, the Mistunobu reaction has been employed to farnesylate a solid supported peptide using farnesol as a shelf stable and relatively inexpensive reagent in order to prepare farnesyl peptide 4.

\section{Results and Discussion}

Peptide 1 was prepared by standard solid-phase synthesis using a Fmoc/tBu strategy on 2-chlorotrityl chloride resin (Scheme 1) [8]. After removal of the $N$-terminal Fmoc protection, an para-nitrosulfonyl (Nosyl) group was installed by treating the resin-bound peptide with nosyl chloride and di-isopropylethylamine in DMF [9,10]. The Mitsunobu reaction was performed using farnesol, diethylazodicarboxylate and triphenylphosphine in THF to install the farnesyl chain. The nosyl group was cleaved using thiophenol and DBU in DMF [11]. Farnesylated peptide 4 was cleaved from the resin using a cocktail of 95:2.5:2.5 TFA/TES/ $\mathrm{H}_{2} \mathrm{O}$, precipitated in cold ether, centrifuged, filtered and washed with ether. Purification by RP-HPLC gave farnesyl peptide 4 in $89 \%$ purity and $2.5 \%$ overall yield: HRMS Calcd. $\left(\mathrm{C}_{60} \mathrm{H}_{96} \mathrm{~N}_{13} \mathrm{O}_{13}\right)^{+}=1206.7245$, found $=1206.7263(\mathrm{M}+\mathrm{H})^{+}$.

\section{Conclusion}

In conclusion, a novel solid-supported lipidation by $N$-alkylation using a Mitsunobu reaction between an alcohol and a nosyl-protected amine was developed and used to install a farnesyl residue on a model peptide. This method provides a viable alternative to the use of costly and unstable farnesyl bromide. The potential for $N$-prenylation to improve metabolic stability and membrane association of peptides is being explored and will be reported in due time. 


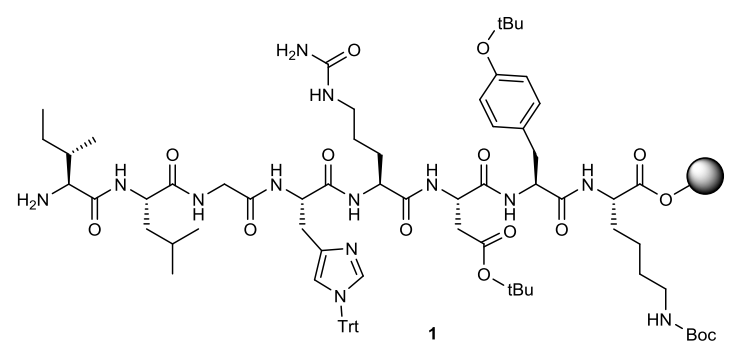

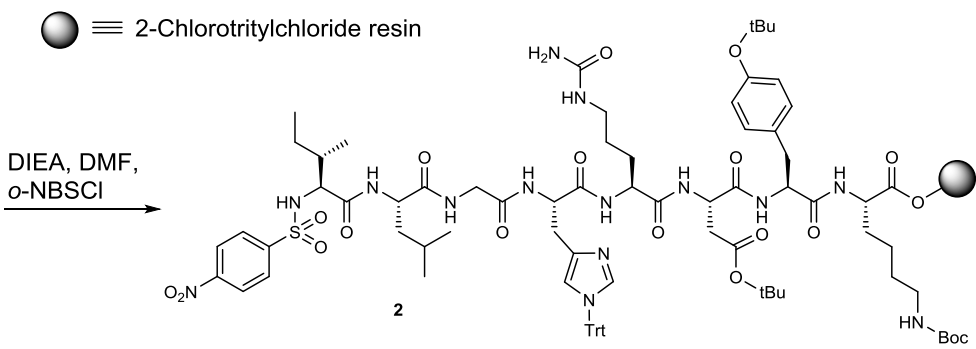

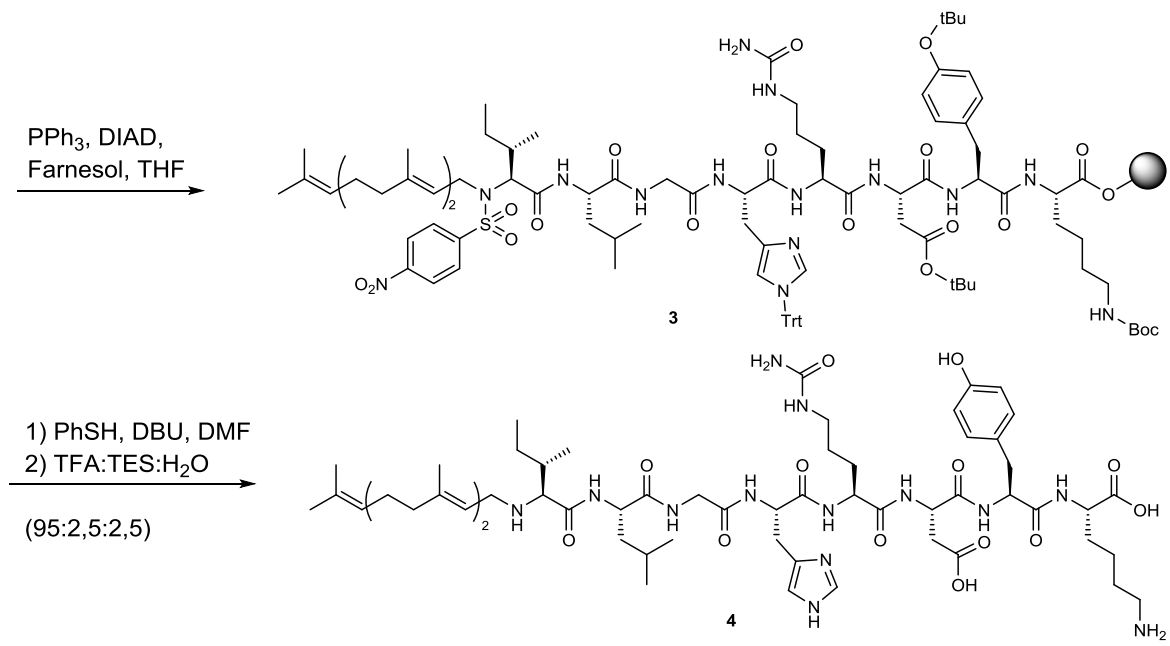

Scheme 1. Synthesis of farnesyl peptide.

\section{Acknowledgments}

The authors would like to thank the Natural Sciences and Engineering Research Council of Canada (NSERC), the Canadian Institutes of Health Research (CIHR), and the March of Dimes foundation

\section{References}

1. Hottman, D.A., Li, L. Mol. Neurobiol. 50, 177-185 (2014), http://dx.doi.org/10.1007/s12035-013-8627-z

2. Xu, N., et al. Sci. China. Life Sci. 58, 328-335 (2015), http://dx.doi.org/10.1007/s11427-015-4836-1

3. Wollack, J.W., et al. J. Am. Chem. Soc. 131, 7293-7303 (2009), http://dx.doi.org/10.1021/ja805174z

4. Yi, L., et al. Chem. Biochem. 12, 2413-2417 (2011), http://dx.doi.org/10.1002/cbic.201100466

5. Dolence, E.K., et al. J. Comb. Chem. 2, $522-536$ (2000), http://dx.doi.org/10.1021/cc000026m

6. Peri, K., et al. Semin. Perinatol. 26, 389-397 (2002), http://dx.doi.org/10.1053/sper.2002.37307

7. Böttcher, B., et al. Hum. Reprod. 29, 2465-2473 (2014), http://dx.doi.org/10.1093/humrep/deu205

8. Lubell, W.D., et al. (2005) "Peptides" Science of Synthesis 21.11, Chemistry of Amides. Thieme, Stuttgart, 713-809.

9. Bisegger, P., et al. Tetrahedron 64, 7531-7536 (2008), http://dx.doi.org/10.1016/j.tet.2008.05.119

10. Arya, P.W., et al. J. Comb. Chem. 6, 65-72 (2004), http://dx.doi.org/10.1021/cc0340067

11. Lencina, C.L., et al. Tetrahedron: Asymm. 19, 1689-1697 (2008), http://dx.doi.org/10.1016/j.tetasy.2008.06.030 